\title{
Factors Influencing Nitrogen Removal in a Decentralized Sewage Treatment Reactor
}

\author{
Dong-Sheng Shen, ${ }^{1,2}$ Bao-Cheng Huang, ${ }^{1,2}$ Pei-Qing Liu, ${ }^{3}$ \\ Jian-Xun Han, ${ }^{4}$ and Hua-Jun Feng ${ }^{1,2}$ \\ ${ }^{1}$ College of Environmental Science and Engineering, Zhejiang Gongshang University, Zhejiang, Hangzhou 310018, China \\ ${ }^{2}$ Zhejiang Provincial Key Laboratory of Solid Waste Treatment and Recycling, Zhejiang Gongshang University, Zhejiang, \\ Hangzhou 310018, China \\ ${ }^{3}$ China SINOMACH Heavy Industry Corporation, Beijing 100102, China \\ ${ }^{4}$ Juhua Group Corporation, Zhejiang, Quzhou 324004, China
}

Correspondence should be addressed to Hua-Jun Feng; fenghuajun@mail.zjgsu.edu.cn

Received 27 June 2012; Revised 13 August 2012; Accepted 13 August 2012

Academic Editor: Wenshan Guo

Copyright (C) 2013 Dong-Sheng Shen et al. This is an open access article distributed under the Creative Commons Attribution License, which permits unrestricted use, distribution, and reproduction in any medium, provided the original work is properly cited.

\begin{abstract}
A decentralized sewage treatment reactor was designed to treat wastewater in rural areas. To examine the factors influencing nitrogen removal, experiments were carried out at three levels of hydraulic surface load, three sludge concentrations, and three environment temperatures at low dissolved oxygen concentrations. The rate of denitrification decreased, and the rate of nitrification increased as the surface load rose. The maximum denitrification rate was $20.01 \pm 3.02 \mathrm{~g} /\left(\mathrm{m}^{3} \cdot \mathrm{d}\right)$ at a surface load of $1.11 \pm$ $0.13 \mathrm{~m}^{3} /\left(\mathrm{m}^{2} \cdot \mathrm{h}\right)$. The total nitrogen $(\mathrm{TN})$ removal, efficiency initially increased and then decreased as the sludge concentration rose. When the sludge concentration increased to $3.5 \pm 0.3 \mathrm{~g} / \mathrm{L}$, the system showed a good level of TN removal and a denitrification rate of $28.58 \pm 1.22 \mathrm{~g} /\left(\mathrm{m}^{3} \cdot \mathrm{d}\right)$ was achieved. Low temperature had a negative effect on the removal and transformation of nitrogenous pollutants.
\end{abstract}

\section{Introduction}

The rate of sewage treatment in rural areas in China is low, and the majority of untreated sewage is discharged directly into lakes and rivers [1]. Many small communities in rural areas still lack domestic wastewater treatment facilities [2]. Sewage carries a high loading of organic and hazardous chemicals and is potentially damaging to human health [3]. Consequently, the treatment of sewage in rural areas in China has become an urgent task and is receiving much attention.

Several decentralized sewage treatment processes [4-6] have been developed and applied to sewage treatment in rural areas. These technologies (and their disadvantages) include anaerobic processes (ineffective ammonia nitrogen removal), constructed wetlands (large site area), oxidation ponds (low treatment efficiency) and soil treatment systems (low treatment efficiency). These technologies have not been widely applied in rural areas because of their shortcomings and are not as effective as aerobic treatment in terms of effluent quality. Aeration allows organic contaminants to be completely degraded by microorganisms into carbon dioxide and water. Aeration is, therefore, suitable for sewage treatment in rural areas. However, aerobic treatment is not widely used in rural areas because the aerobic activated sludge process requires a relatively strict operation and management regime $[7,8]$. In addition, the aeration tank readily deteriorates without professional maintenance. The complicated structure, relative high energy consumption, and difficult management of aerobic treatment systems limit their application in rural areas.

The key challenge in solving the nonpoint-source pollution problem in China is the development of a treatment process with a simple structure, low operating costs, and easy management that can match aerobic treatment in terms of effluent quality. Based on this understanding, we designed an integrated decentralized sewage treatment 
reactor (DSTR). The DSTR consists of a sludge separation device and an aeration tank. The sludge separation device has been granted patent rights by the State Intellectual Property Office of the People's Republic of China (patent number 201120250513.X). By combining sludge separation with an aeration tank, the site area is reduced and a sludge recirculation system is not needed, thereby decreasing the operating costs compared with activated sludge reactors. After start up, DSTRs rarely need operational or management input. To evaluate the feasibility of DSTRs in terms of engineering application, their performance was studied using small experiments and pilot tests. The average removal efficiencies of total chemical oxygen demand, $\mathrm{NH}_{4}{ }^{+}$-N, suspended solids and turbidity were $76 \%, 77.15 \%, 84.17 \%$, and $83.93 \%$, respectively. The DSTR exhibited good performance by initial promotion and application in small scale. The discharge of excess sludge is needed in traditional aerobic process. But in DSTR, sludge can be discharged periodic to ensure the sludge concentration in a suitable value. It has great potential for the treatment of rural sewage on a large scale.

In aerobic tanks, ammonia nitrogen is usually converted to nitrate by biological nitrification. Denitrification does not readily occur in aerobic tanks, and the nitrogen removal effect is not significant in such systems. The objective of this study was to investigate nitrogen removal in DSTRs by regulating and controlling macroscopic operation parameters. The aim of this study was to enhance simultaneous nitrification and denitrification (SND) under low dissolved oxygen (DO) concentrations and to obtain the optimal DSTR operation parameters. The experimental results should support the theoretical basis for the further popularization and application of DSTRs.

\section{Materials and Methods}

2.1. Experimental Setup. A set of DSTRs, as illustrated in Figure 1, was used in this study. The main reactor compartments consisted of an influent plastic tank (200 L), an aeration tank (length $1 \mathrm{~m}$, width $0.65 \mathrm{~m}$, height $1 \mathrm{~m}$ ), and an integrated sludge separating device (inner cylinder diameter $0.14 \mathrm{~m}$, height $0.27 \mathrm{~m}$, external cylinder diameter $0.27 \mathrm{~m}$, height $0.5 \mathrm{~m}$ ). The sludge separating device was fastened by four support pillars to the center of the aeration tank. The distance between the sludgeseparation device and the bottom of the aeration tank was $0.4 \mathrm{~m}$. Sewage was pumped by a centrifugal pump (LangHe Company, Shanghai, China) into the influent plastic tank, and a peristaltic pump (Lange Company, Baoding, China) was used to control the influent and effluent flow rates. Two aeration pumps were used to oxygenate the contents of the reactor. The air was diffused using several aerators.

Seed sludge collected from Qige wastewater treatment plant (Hangzhou, China) was incubated and acclimated in sewage before the experiments. The total suspended solids (TSS) and volatile suspended solids of the sludge were 8.62 and $4.38 \mathrm{~g} / \mathrm{L}$, respectively. The initial inoculation concentration of sludge was $1.5 \mathrm{~g} / \mathrm{L}$. Sewage was pumped into the reactor. The sewage had a chemical oxygen demand (COD) of $179-514 \mathrm{mg} / \mathrm{L}$, a suspended solids level of $40-535 \mathrm{mg} / \mathrm{L}$, a turbidity of 61-370 NTU and $\mathrm{NH}_{4}{ }^{+}-\mathrm{N}$ levels of $21-42 \mathrm{mg} / \mathrm{L}$. The DO concentration was maintained at $1.3 \pm 0.2 \mathrm{mg} / \mathrm{L}$ during the experiments.

2.2. Experimental Design. After the inoculation of sludge, the reactor was run for about 10 days to allow it to stabilize. The experiment was then conducted in three stages. First, the effect of different surface loads was investigated. Surface loads of $1.11 \pm 0.13,1.56 \pm 0.13$ and $1.89 \pm 0.05 \mathrm{~m}^{3} /\left(\mathrm{m}^{2} \cdot \mathrm{h}\right)$ were studied at a sludge concentration of $1.8 \pm 0.3 \mathrm{~g} / \mathrm{L}$. Second, the influence of sludge concentration on nitrogen migration and transformation was studied. Sludge concentrations of $1.5 \pm 0.2,3.5 \pm 0.3$ and $4.5 \pm 0.7 \mathrm{~g} / \mathrm{L}$ were used at a surface load of $2.0 \pm 0.5 \mathrm{~m}^{3} /\left(\mathrm{m}^{2} \cdot \mathrm{h}\right)$. Third, the reactor was run at a surface load of $2.0 \pm 0.5 \mathrm{~m}^{3} /\left(\mathrm{m}^{2} \cdot \mathrm{h}\right)$ and a sludge concentration of 2.0 $\pm 0.3 \mathrm{~g} / \mathrm{L}$ for a period of time to investigate the influence of ambient temperature on nitrogen transformation.

2.3. Analytical Method. $\mathrm{NH}_{4}{ }^{+}-\mathrm{N}, \mathrm{NO}_{3}{ }^{-}-\mathrm{N}, \mathrm{NO}_{2}{ }^{-}-\mathrm{N}, \mathrm{TN}$, mixed liquor suspended solid (MLSS) and mixed liquor volatile suspended solid (MLVSS) levels were measured using the standard methods [9]. The concentration of Kjeldahl nitrogen was calculated on the basis of $\mathrm{TN}, \mathrm{NO}_{3}{ }^{-}-\mathrm{N}$, and $\mathrm{NO}_{2}{ }^{-}$-N. COD was measured using a DR2800 spectrophotometer (HACH Company, Loveland, CO, USA). DO was measured using a DO meter (INESA Scientific Instrument company, Shanghai, China) and $\mathrm{pH}$ was measured by a $\mathrm{pH}$ meter (Mettler Toledo, Greifensee, Switzerland).

Nitrogen migration and transformation in the traditional biological nitrogen removal process is as follows:

$$
\begin{gathered}
\mathrm{NH}_{4}{ }^{+}-\mathrm{N} \longrightarrow \mathrm{NO}_{2}{ }^{-}-\mathrm{N} \longrightarrow \mathrm{NO}_{3}{ }^{-}-\mathrm{N} \longrightarrow \mathrm{NO}_{2}{ }^{-}-\mathrm{N} \\
\longrightarrow \mathrm{NO} \longrightarrow \mathrm{N}_{2} \mathrm{O} \longrightarrow \mathrm{N}_{2}
\end{gathered}
$$

$\mathrm{NH}_{4}{ }^{+}-\mathrm{N}$ removal is accomplished by nitrification and $\mathrm{TN}$ is removed by denitrification. The rates of nitrification and denitrification in this study were calculated as follows [10]:

$$
\begin{aligned}
& r_{\text {nitrification }}=\frac{\mathrm{Q}_{\text {in }}\left(\mathrm{KN}_{\text {influent }}-\mathrm{KN}_{\text {effluent }}\right)}{V_{\text {reactor }}}, \\
& r_{\text {denitrification }}=\frac{Q_{\text {in }}\left(\mathrm{TN}_{\text {influent }}-\mathrm{TN}_{\text {effluent }}\right)}{V_{\text {reactor }}},
\end{aligned}
$$

where $Q_{\text {in }}$ is the influent flux $(\mathrm{L} / \mathrm{d}), V_{\text {reactor }}$ is the volume of the reactor excluding the sludge sedimentation device $(\mathrm{L})$, $\mathrm{KN}$ is Kjeldahl nitrogen $(\mathrm{mg} / \mathrm{L})$, and $\mathrm{TN}$ is total nitrogen (mg/L).

\section{Results and Discussion}

\subsection{Results}

3.1.1. $\mathrm{NH}_{4}{ }^{+}-\mathrm{N}$ and TN Removal. The $\mathrm{NH}_{4}{ }^{+}-\mathrm{N}$ and $\mathrm{TN}$ concentrations in the influent and effluent during the operation period are shown in Figure 2. The effluent $\mathrm{NH}_{4}{ }^{+}$$\mathrm{N}$ concentration was steady under low surface loads, but 


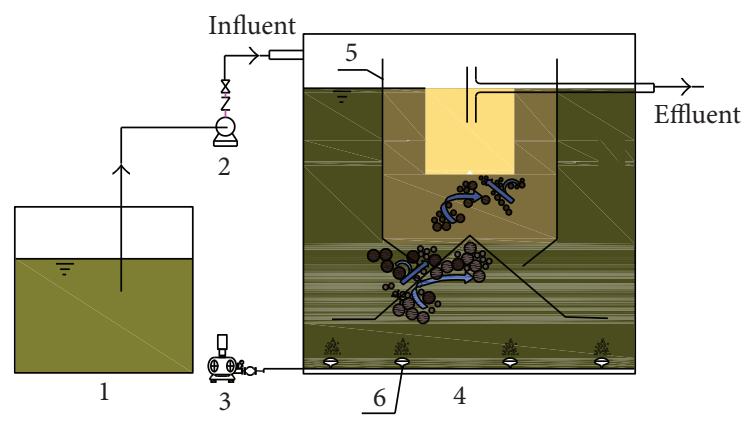

Figure 1: Experimental configuration of a decentralized sewage treatment reactor (DSTR) system 1, Influent plastic tank; 2, peristaltic pump; 3 , aeration pump; 4, DSTR reactor; 5, sludge sedimentation device; 6 , aerator.

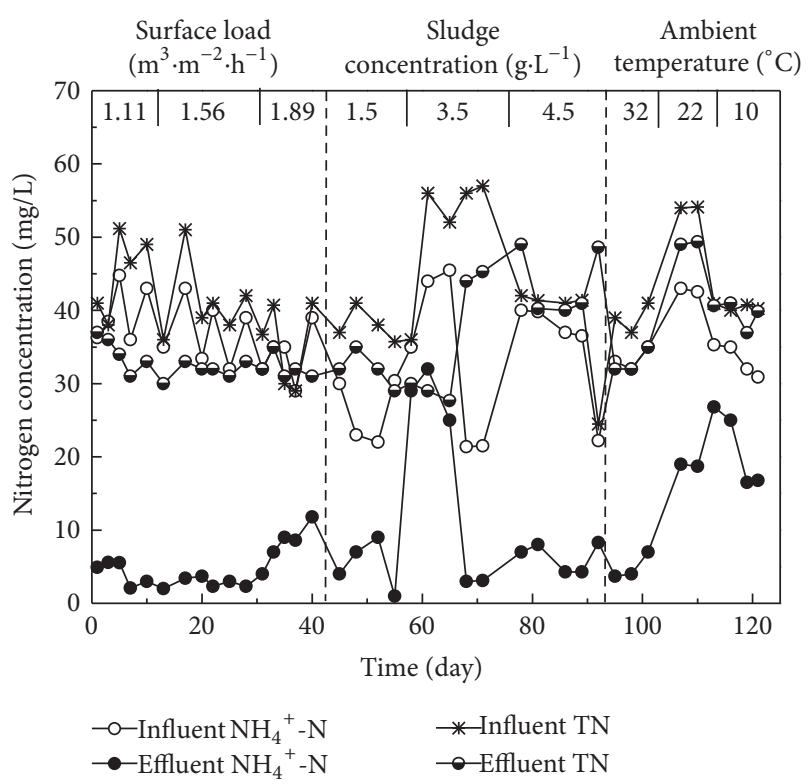

FIgURE 2: TN and $\mathrm{NH}_{4}{ }^{+}-\mathrm{N}$ removal in a DSTR system.

it increased considerably at intermediate sludge concentrations. In addition, at high sludge concentrations, the TN concentration in the effluent was almost the same as that in the influent. Occasionally, TN was even higher than that in the influent. This phenomenon was probably caused by organic nitrogen emission from the system. When the ambient temperature decreased, the $\mathrm{NH}_{4}{ }^{+}-\mathrm{N}$ concentration in the effluent increased, indicating that low temperature adversely affects nitrification. These data suggest that sludge concentration and temperature have an influence on the effectiveness of $\mathrm{NH}_{4}{ }^{+}-\mathrm{N}$ and TN removal.

3.1.2. Effluent $\mathrm{NO}_{3}{ }^{-}-\mathrm{N}$ and $\mathrm{NO}_{2}{ }^{-}-\mathrm{N}$ Concentration and COD Removal. Figure 3 shows the $\mathrm{NO}_{3}{ }^{-}-\mathrm{N}, \mathrm{NO}_{2}{ }^{-}-\mathrm{N}$ and COD concentrations in the effluent. The nitrite concentration in the effluent was mostly below $0.6 \mathrm{mg} / \mathrm{L}$, except for intermediate sludge concentrations. Nitrite accumulation was not evident. The nitrate concentration in the effluent was relatively stable during the surface loading stage, but there were fluctuations during the sludge concentration and temperature stages. The COD in the effluent followed a similar trend to that of the nitrate concentration. The effluent COD concentration was below $70 \mathrm{mg} / \mathrm{L}$, despite variation of the influent quality, during the surface load stage, and the system exhibited a good level of organic removal. However, the sludge concentration and temperature had a great impact on COD removal.

\subsection{Discussion}

3.2.1. Effect of Surface Load on Nitrogen Removal. The effect of surface load on nitrogen migration and transformation is shown in Table 1. Both the TN and $\mathrm{NH}_{4}{ }^{+}-\mathrm{N}$ concentrations in effluent increased as surface loads increased. Table 2 shows that the maximal denitrification rate of $20.01 \pm 3.02 \mathrm{~g} /\left(\mathrm{m}^{3} \cdot \mathrm{d}\right)$ was achieved at a surface load of $1.11 \pm 0.13 \mathrm{~m}^{3} /\left(\mathrm{m}^{2} \cdot \mathrm{h}\right)$. When the surface load increased to $1.89 \pm 0.05 \mathrm{~m}^{3} /\left(\mathrm{m}^{2} \cdot \mathrm{h}\right)$, the rate of denitrification decreased to its minimum value. In contrast, the nitrification rate increased as the surface load rose.

Some researchers have found that the efficiency of biological treatment system depends on operating conditions such as hydraulic retention time [11]. A huge number of microorganisms are present in activated sludge systems, and most of them unite to form a zoogloea. Aerobic heterotrophic bacteria responsible for carbon removal accompanied by nitrifiers are in the exterior of the zoogloea. In activated sludge systems, denitrification is significantly influenced by oxygen and substrate concentration. At low surface loads, nutrient is removed by heterotrophic bacteria in the external layer of sludge flocs; denitrifiers in the inner layer lack an adequate carbon source. Although the amount of organic substrate increased as surface load rose, most of it was degraded by heterotrophic bacteria. The amount of heterotrophic bacteria was large and the anoxic zone contracted as the surface load increased. The denitrifiers were, therefore, starved of food. In addition, low DO concentrations $(0.15-0.35 \mathrm{mg} / \mathrm{L})$ were beneficial to the SND process [12]. The concentration of DO in this study was maintained at 1.3 $\pm 0.2 \mathrm{mg} / \mathrm{L}$, and this fact might have restricted the formation of an anoxic zone and thereby restrained the denitrification process. During the low surface load phase, both oxygen and substrate levels were not suitable for denitrification. The finding that the nitrification rate increased when the surface load rose indicates that nitrification might not be carried out by aerobic autotrophic nitrifiers alone. Aerobic heterotrophic nitrifiers might also be responsible for nitrogen migration. Heterotrophic nitrification has been shown to contribute to ammonia removal in wastewater $[13,14]$. As the surface load increased, the heterotrophic nitrification process was strengthened and this could accelerate the ammonia oxidation process. And it could be seen from the Figure 3 that the effluent COD was stable as surface load varied [15]. found that the hydraulic retention had no significant effect on granular sludge biomass in treating textile wastewater. 
TABLE 1: Nitrogen removal in a DSTR at different surface loads.

\begin{tabular}{lccccc}
\hline \multirow{2}{*}{ Surface load $\left(\mathrm{m}^{3} /\left(\mathrm{m}^{2} \cdot \mathrm{h}\right)\right)$} & \multicolumn{2}{c}{$\mathrm{TN}(\mathrm{mg} / \mathrm{L})$} & \multicolumn{2}{c}{$\mathrm{NH}_{4}{ }^{+}-\mathrm{N}(\mathrm{mg} / \mathrm{L})$} & \multirow{2}{*}{ Effluent NO${ }^{-}{ }^{-} \mathrm{N}(\mathrm{mg} / \mathrm{L})$} \\
& Influent & Effluent & Influent & Effluent & \\
\hline $1.11 \pm 0.13$ & $49.55 \pm 2.65$ & $32.60 \pm 1.73$ & $41.26 \pm 4.64$ & $3.68 \pm 1.76$ & $28.19 \pm 0.47$ \\
$1.56 \pm 0.13$ & $40.57 \pm 1.50$ & $33.27 \pm 1.70$ & $35.80 \pm 2.88$ & $4.33 \pm 2.41$ & $28.07 \pm 0.46$ \\
$1.89 \pm 0.05$ & $41.04 \pm 8.87$ & $36.11 \pm 8.83$ & $34.64 \pm 5.81$ & $10.07 \pm 6.18$ & $22.75 \pm 3.57$ \\
\hline
\end{tabular}

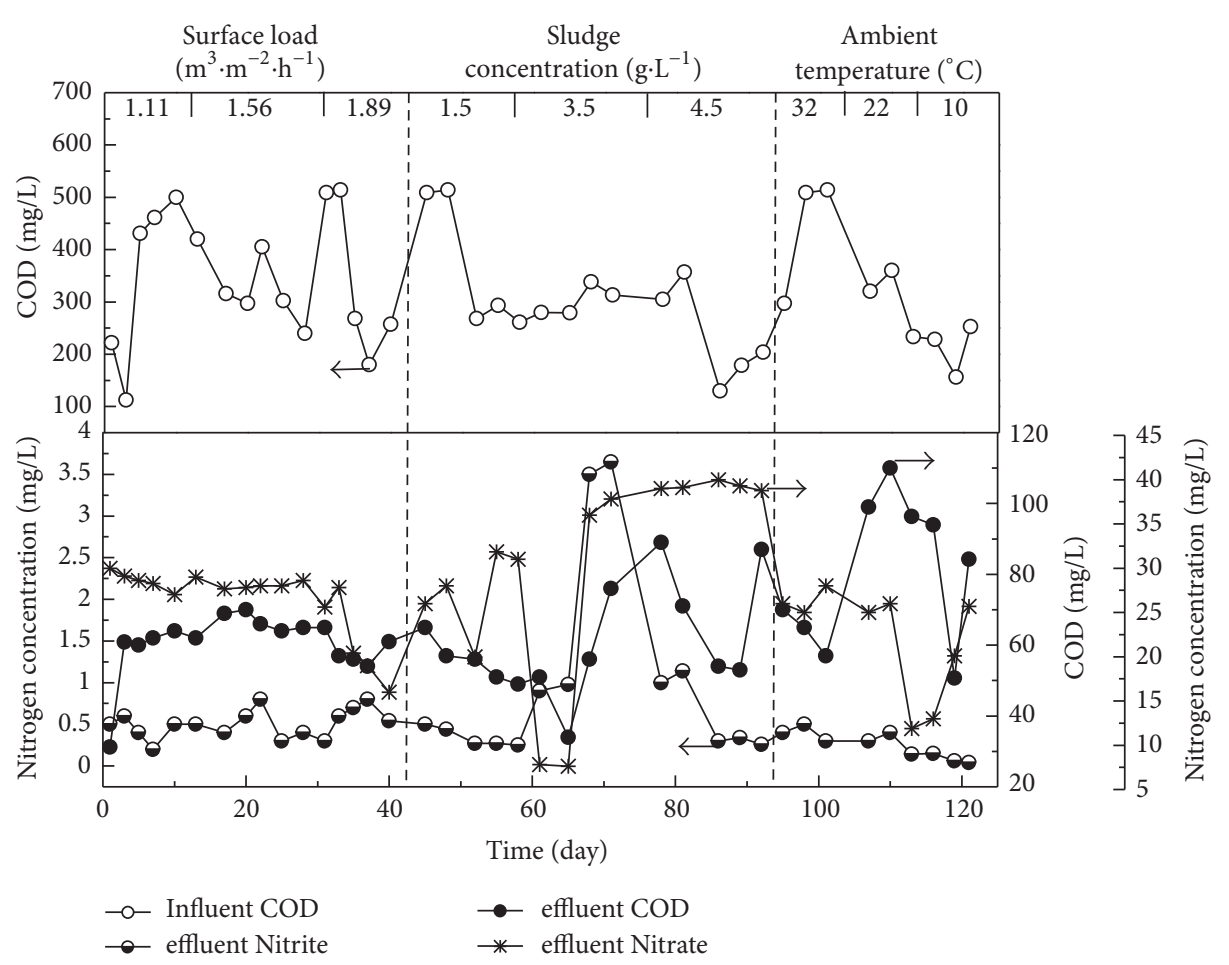

FIGURE 3: Effluent nitrate and nitrite concentrations and COD removal in a DSTR system.

TABLE 2: Nitrification and denitrification rates in a DSTR at different surface loads.

\begin{tabular}{lccc}
\hline Surface load $\left(\mathrm{m}^{3} /\left(\mathrm{m}^{2} \cdot \mathrm{h}\right)\right)$ & $1.11 \pm 0.13$ & $1.56 \pm 0.13$ & $1.89 \pm 0.05$ \\
\hline$r_{\text {nitrification }}\left(\mathrm{g} /\left(\mathrm{m}^{3} \cdot \mathrm{d}\right)\right)$ & $53.09 \pm 6.41$ & $59.62 \pm 2.82$ & $61.44 \pm 0.48$ \\
$r_{\text {denitrification }}\left(\mathrm{g} /\left(\mathrm{m}^{3} \cdot \mathrm{d}\right)\right)$ & $20.01 \pm 3.02$ & $11.97 \pm 2.39$ & $9.81 \pm 3.17$ \\
\hline
\end{tabular}

In this study, as the surface load rose, the nitrification rate increased, whereas the denitrification rate decreased. As a result, the low surface load of $1.11 \pm 0.13 \mathrm{~m}^{3} /\left(\mathrm{m}^{2} \cdot \mathrm{h}\right)$ was beneficial to biological nitrogen removal.

\subsubsection{Effect of Sludge Concentration on Nitrogen Removal.} $\mathrm{TN}$ and $\mathrm{NH}_{4}^{+}-\mathrm{N}$ levels in the influent and effluent and $\mathrm{NO}_{3}{ }^{-}-\mathrm{N}$ and $\mathrm{NO}_{2}{ }^{-}-\mathrm{N}$ levels in the effluent are shown in Table 3. The $\mathrm{NH}_{4}{ }^{+}-\mathrm{N}$ and $\mathrm{TN}$ concentrations in effluent rose slightly when the sludge concentration increased from 1.5 \pm 0.2 to $3.5 \pm 0.03 \mathrm{~g} / \mathrm{L}$. Nitrite accumulation was observed in the system. Kim et al. [16] also found that the increased sludge concentration in the nitrification tank via SRT control enhanced TN removal. Acceleration of the nitrification and denitrification rates can be seen in Table 4 when the sludge concentration increased from $1.5 \pm 0.2$ to $3.5 \pm 0.03 \mathrm{~g} / \mathrm{L}$. However, when the sludge concentration increased from $3.5 \pm 0.3$ to $4.5 \pm 0.7 \mathrm{~g} / \mathrm{L}$, the TN concentration in the effluent was higher than that in the influent.

As the sludge concentration increased, the number of nitrifiers increased, which resulted in an increase of the volume removal rate of Kjeldahl nitrogen. However, the removal rate of Kjeldahl nitrogen per gram MLSS decreased, indicating that nitrification was inhibited. During the nitrification process, adequate DO is needed to achieve a good level of ammonia oxidation [17]. However, the DO was consumed primarily by aerobic heterotrophic microorganisms, and, as a result, the rate of nitrification decreased.

When the sludge concentration was maintained at $3.5 \pm$ $0.3 \mathrm{~g} / \mathrm{L}$, the system achieved its optimum level of denitrification. The removal of nitrogen per gram MLSS increased when the sludge concentration increased from $1.5 \pm 0.2$ to $3.5 \pm 0.03 \mathrm{~g} / \mathrm{L}$. This phenomenon was probably caused by the consumption of oxygen by aerobic bacteria, which resulted in an increased anoxic area in activated sludge flocs. However, when the sludge concentration increased to $4.5 \pm 0.7 \mathrm{~g} / \mathrm{L}$, the autolysis of sludge likely occurred, leading to a higher $\mathrm{TN}$ concentration in the effluent than in the influent. Based 
TABLE 3: Nitrogen removal in a DSTR at different sludge concentrations.

\begin{tabular}{lcccccc}
\hline \multirow{2}{*}{ Sludge concentration $(\mathrm{g} / \mathrm{L})$} & \multicolumn{2}{c}{$\mathrm{TN}(\mathrm{mg} / \mathrm{L})$} & \multicolumn{2}{c}{$\mathrm{NH}_{4}{ }^{+}-\mathrm{N}(\mathrm{mg} / \mathrm{L})$} & \multirow{2}{*}{ Effluent NO ${ }_{3}{ }^{-}-\mathrm{N}(\mathrm{mg} / \mathrm{L})$} & \multirow{2}{*}{ Effluent NO${ }^{-}-\mathrm{N}(\mathrm{mg} / \mathrm{L})$} \\
& Influent & Effluent & Influent & Effluent & & \\
\hline $1.5 \pm 0.2$ & $38.63 \pm 2.00$ & $32.77 \pm 2.11$ & $34.00 \pm 1.73$ & $6.67 \pm 2.52$ & $24.60 \pm 3.80$ & $0.47 \pm 0.04$ \\
$3.5 \pm 0.3$ & $48.25 \pm 11.13$ & $34.06 \pm 9.76$ & $24.79 \pm 4.86$ & $9.45 \pm 12.9$ & $25.76 \pm 15.99$ & $1.63 \pm 1.78$ \\
$4.5 \pm 0.7$ & $35.75 \pm 9.74$ & $43.27 \pm 4.63$ & $32.83 \pm 9.36$ & $6.87 \pm 2.23$ & $39.05 \pm 0.27$ & $0.58 \pm 0.49$ \\
\hline
\end{tabular}

TABLE 4: Nitrification and denitrification rates in a DSTR at different sludge concentrations.

\begin{tabular}{lccc}
\hline Sludge concentration $(\mathrm{g} / \mathrm{L})$ & $1.5 \pm 0.2$ & $3.5 \pm 0.03$ & $4.5 \pm 0.7$ \\
\hline$r_{\text {nitrification }}\left(\mathrm{g} /\left(\mathrm{m}^{3} \cdot \mathrm{d}\right)\right)$ & $57.36 \pm 3.26$ & $80.61 \pm 19.03$ & $61.87 \pm 36.34$ \\
$r_{\text {denitrification }}\left(\mathrm{g} /\left(\mathrm{m}^{3} \cdot \mathrm{d}\right)\right)$ & $11.03 \pm 2.20$ & $28.58 \pm 1.22$ & $/$ \\
$r_{\text {nitrification }}(\mathrm{mg} /(\mathrm{gMLSS} \cdot \mathrm{d}))$ & $30 \pm 3$ & $20 \pm 5$ & $10 \pm 8$ \\
$r_{\text {denitrification }}(\mathrm{mg} /(\mathrm{gMLSS} \cdot \mathrm{d}))$ & $6 \pm 1$ & $7 \pm 4$ & $/$ \\
\hline
\end{tabular}

TABLE 5: Nitrification and denitrification rates in a DSTR at different ambient temperatures.

\begin{tabular}{lccc}
\hline Temperature $\left({ }^{\circ} \mathrm{C}\right)$ & $32 \pm 1$ & $22 \pm 1$ & $10 \pm 3$ \\
\hline$r_{\text {nitrification }}\left(\mathrm{g} /\left(\mathrm{m}^{3} \cdot \mathrm{d}\right)\right)$ & $60.08 \pm 2.22$ & $71.47 \pm 23.06$ & $35.87 \pm 0.40$ \\
$r_{\text {denitrification }}\left(\mathrm{g} /\left(\mathrm{m}^{3} \cdot \mathrm{d}\right)\right)$ & $10.63 \pm 1.53$ & $1.43 \pm 0.68$ & $0.46 \pm 0.09$ \\
\hline
\end{tabular}

on the removal rates of nitrogen for sludge concentrations of $1.5 \pm 0.2$ and $3.5 \pm 0.3 \mathrm{~g} / \mathrm{L}$, a linear extrapolation would suggest a nitrogen removal rate of $38 \mathrm{~g} /\left(\mathrm{m}^{3} \cdot \mathrm{d}\right)$ for a sludge concentration of $4.5 \pm 0.7 \mathrm{~g} / \mathrm{L}$. However, no nitrogen removal was observed at a sludge concentration of $4.5 \pm 0.7 \mathrm{~g} / \mathrm{L}$. Therefore, it appears that a high sludge concentration can have a negative effect on nitrogen removal. From the above analysis, we suggest that the appropriate sludge concentration when treating sewage in a DSTR system is $3.5 \mathrm{~g} / \mathrm{L}$.

\subsubsection{Effect of Ambient Temperature on Nitrogen Removal.} Temperature had a significant impact on nitrogen removal. Most nitrifiers and denitrifiers are mesophilic microorganisms. The optimal temperature for nitrifiers is $25-30^{\circ} \mathrm{C}$ [18]. The enzymes present in these organisms have optimal activity under mesothermal conditions, which is helpful to nitrogen removal. Yuan et al. [19] deemed that the activity of nitrate bacteria was inhibited and caused the $\mathrm{HNO}_{2}$ accumulation when the temperature was between $12-14^{\circ} \mathrm{C}$ or higher than $30^{\circ} \mathrm{C}$. While the temperature was between the $15-30^{\circ} \mathrm{C}$, a well nitrification process was achieved.

The effects of ambient temperature on nitrification and denitrification rates are shown in Table 5. A high temperature $\left(32^{\circ} \mathrm{C}\right)$ was beneficial for denitrification. The rate of denitrification achieved at this temperature was $10.63 \pm 1.53 \mathrm{~g} /\left(\mathrm{m}^{3} \cdot \mathrm{d}\right)$. As the ambient temperature decreased, the denitrification process was greatly inhibited. The effect of ambient temperature on nitrification showed that mesothermal conditions are suitable for a good nitrification process. Low temperatures had a significant adverse impact on nitrification also, underlining that both nitrification and denitrification were inhibited at low temperatures. However, the COD removal efficiency was relatively stable as the ambient temperature changed. Therefore, when the ambient temperature falls, especially in the winter, the water temperature will need to be adjusted to a suitable value to achieve adequate nitrogen removal.

\section{Conclusions}

The rate of denitrification decreased as the surface load increased, but the rate of nitrification increased. The low surface load of $1.11 \pm 0.13 \mathrm{~m}^{3} /\left(\mathrm{m}^{2} \cdot \mathrm{h}\right)$ was the optimum for nitrogen removal in this study. At low DO levels and a sludge concentration of $3.5 \mathrm{~g} / \mathrm{L}$, the system achieved a good level of nitrogen removal. Neither high nor low sludge concentrations were suitable for nitrification and denitrification. Low temperatures also had an adverse effect on nitrification and denitrification. Close consideration of the water temperature is needed to avoid a decline in nitrogen removal when treating sewage in DSTRs.

\section{Acknowledgments}

This work was financially supported by the Natural Science Foundation of China (50908209 and 51208464), the Key Technology Research and Development Program of Science and Technology Department in Zhejiang Province (2010C13001) and the Natural Science Foundation of Zhejiang Province (Y5110019).

\section{References}

[1] L. Xu, H. You, J. Li et al., "Analysis on affected factors of treatment efficiency of rural sewage removal with constructed wetland," Procedia Environmental Sciences, vol. 10, pp. 2314-2319, 2011.

[2] F. Ye and Y. Li, "Enhancement of nitrogen removal in towery hybrid constructed wetland to treat domestic wastewater for small rural communities," Ecological Engineering, vol. 35, no. 7, pp. 1043-1050, 2009.

[3] R. K. Sinha, G. Bharambe, and U. Chaudhari, "Sewage treatment by vermifiltration with synchronous treatment of sludge 
by earthworms: a low-cost sustainable technology over conventional systems with potential for decentralization," Environmentalist, vol. 28, no. 4, pp. 409-420, 2008.

[4] A. Sarti, M. L. Garcia, M. Zaiat, and E. Foresti, "Domestic sewage treatment in a pilot-scale anaerobic sequencing batch biofilm reactor (ASBBR)," Resources, Conservation and Recycling, vol. 51, no. 1, pp. 237-247, 2007.

[5] F. Valdez Zamudio, "Sewage treatment by means of oxidation ponds," Science of the Total Environment, vol. 2, no. 4, pp. 406-409, 1974.

[6] C. Ye, Z. B. Hu, H. N. Kong, X. Z. Wang, and S. B. He, "A new soil inflltration technology for decentralized sewage treatment: two-stage anaerobic tank and soil trench system," Pedosphere, vol. 18, no. 3, pp. 401-408, 2008.

[7] F. A. El-Gohary, S. I. Abou-Elela, S. El-Hawary, S. A. Shehata, H. M. El-Kamah, and H. Ibrahim, "Evaluation of wastewater treatment technologies for rural Egypt," International Journal of Environmental Studies, vol. 54, no. 1, pp. 35-55, 1998.

[8] T. Sabry, "Evaluation of decentralized treatment of sewage employing Upflow Septic Tank/Baffled Reactor (USBR) in developing countries," Journal of Hazardous Materials, vol. 174, no. 1-3, pp. 500-505, 2010.

[9] American Public Health Association, Standard Methods for Examination of Water and Wastewater, American Public Health Association, Washington, DC, USA, 20th edition, 1998.

[10] Z. Fu, F. Yang, F. Zhou, and Y. Xue, "Control of COD/N ratio for nutrient removal in a modified membrane bioreactor (MBR) treating high strength wastewater," Bioresource Technology, vol. 100, no. 1, pp. 136-141, 2009.

[11] A. W. Mayo and J. Mutamba, "Effect of HRT on nitrogen removal in a coupled HRP and unplanted subsurface flow gravel bed constructed wetland," Physics and Chemistry of the Earth A/B/C, vol. 29, no. 15-18, pp. 1253-1257, 2004.

[12] S. M. Hocaoglu, G. Insel, U. U. Cokgor, and D. Orhon, "Effect of low dissolved oxygen on simultaneous nitrification and denitrification in a membrane bioreactor treating black water," Bioresource Technology, vol. 102, no. 6, pp. 4333-4340, 2011.

[13] N. U. D. Ahmad, H. Xu, L. Chen, Z. Liu, and S. Liu, "Enhanced biological nutrient removal by the alliance of a heterotrophic nitrifying strain with a nitrogen removing ecosystem," Journal of Environmental Sciences, vol. 20, no. 2, pp. 216-223, 2008.

[14] J. K. Kim, K. J. Park, K. S. Cho, S. W. Nam, T. J. Park, and R. Bajpai, "Aerobic nitrification-denitrification by heterotrophic Bacillus strains," Bioresource Technology, vol. 96, no. 17, pp. 1897-1906, 2005.

[15] K. Muda, A. Aris, M. R. Salim et al., "The effect of hydraulic retention time on granular sludge biomass in treating textile wastewater," Water Research, vol. 45, no. 16, pp. 4711-4721, 2011.

[16] Y. M. Kim, H. U. Cho, D. S. Lee, D. Park, and J. M. Park, "Influence of operational parameters on nitrogen removal efficiency and microbial communities in a full-scale activated sludge process," Water Research, vol. 45, no. 17, pp. 5785-5795, 2011.

[17] U. Wiesmann, "Biological nitrogen removal from wastewater," Advances in Biochemical Engineering/Biotechnology, vol. 51, pp. 113-154, 1994.

[18] E. Bock, H. P. Koops, H. Harms, and B. Ahlers, "The biomchemistry of nitrifying organisms," in Variations in Autotrophic Life, J. M. Shively and L. L. Barton, Eds., pp. 171-200, Academic Press, London, UK, 1991.

[19] L. J. Yuan, D. C. Peng, and Z. Y. Wang, "Shortcut nitrificationdenitrification," China Water and Wastewater, vol. 16, no. 2, pp. 29-31, 2000. 

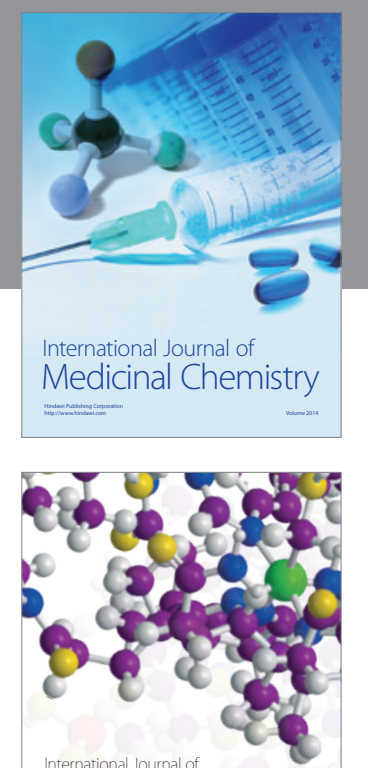

\section{Carbohydrate} Chemistry

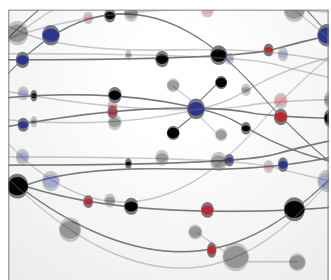

The Scientific World Journal
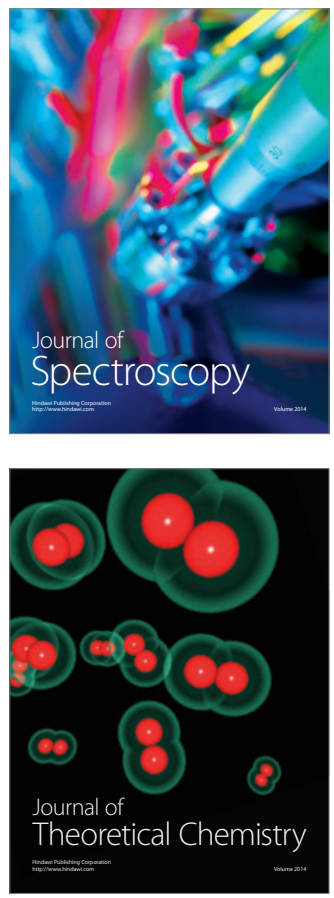
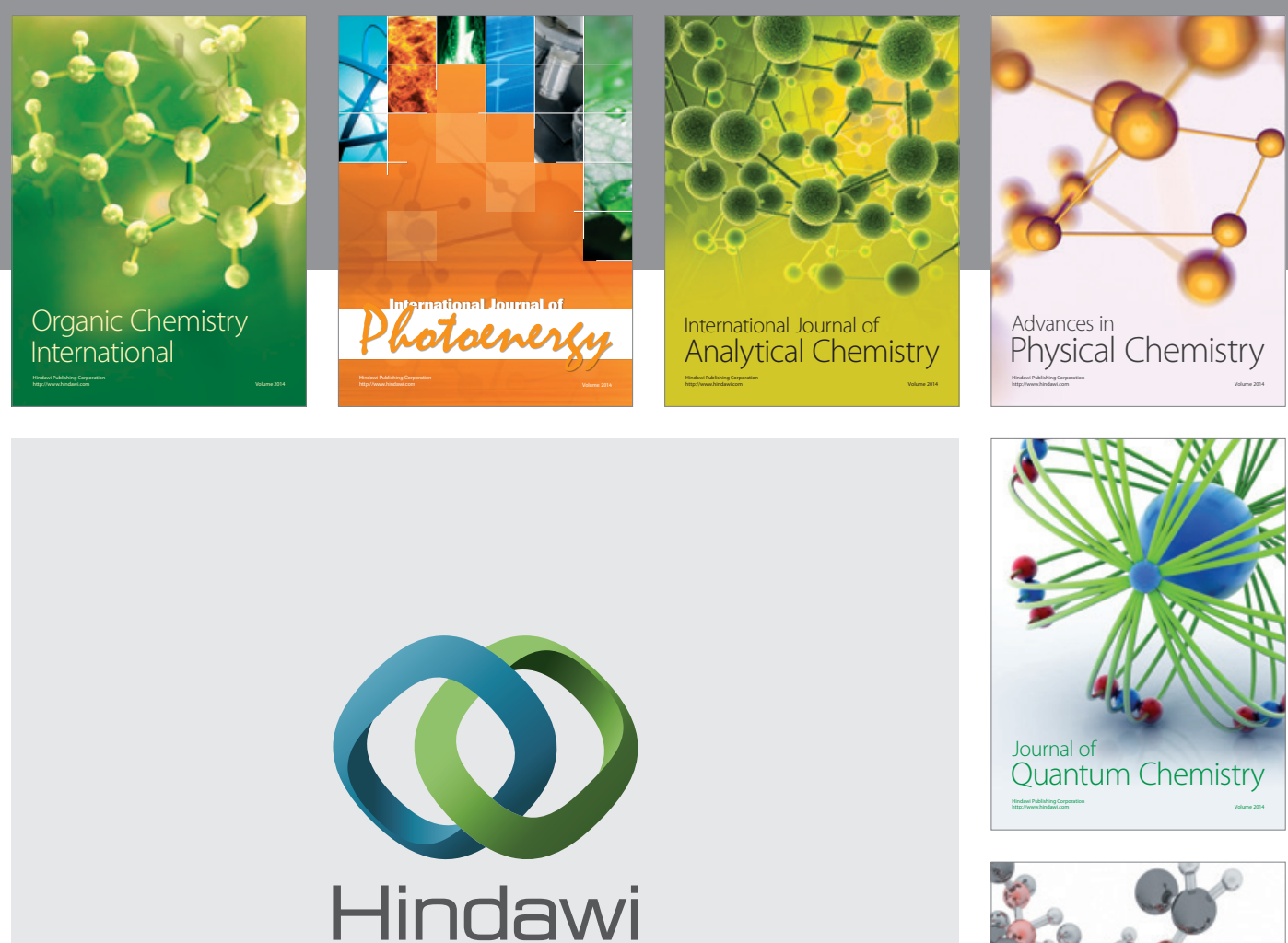

Submit your manuscripts at

http://www.hindawi.com

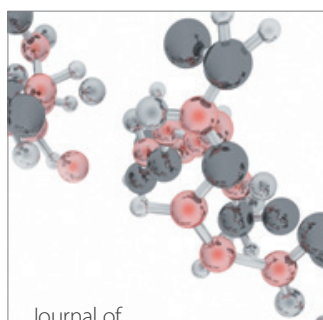

Analytical Methods

in Chemistry

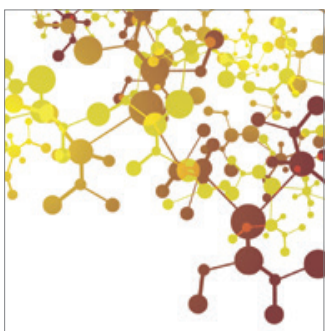

Journal of

Applied Chemistry

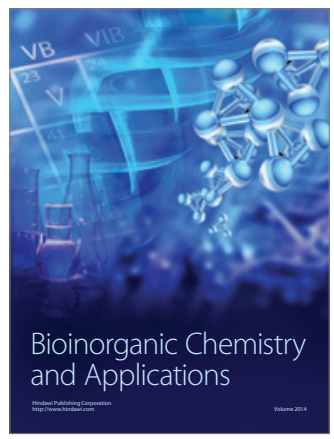

Inorganic Chemistry
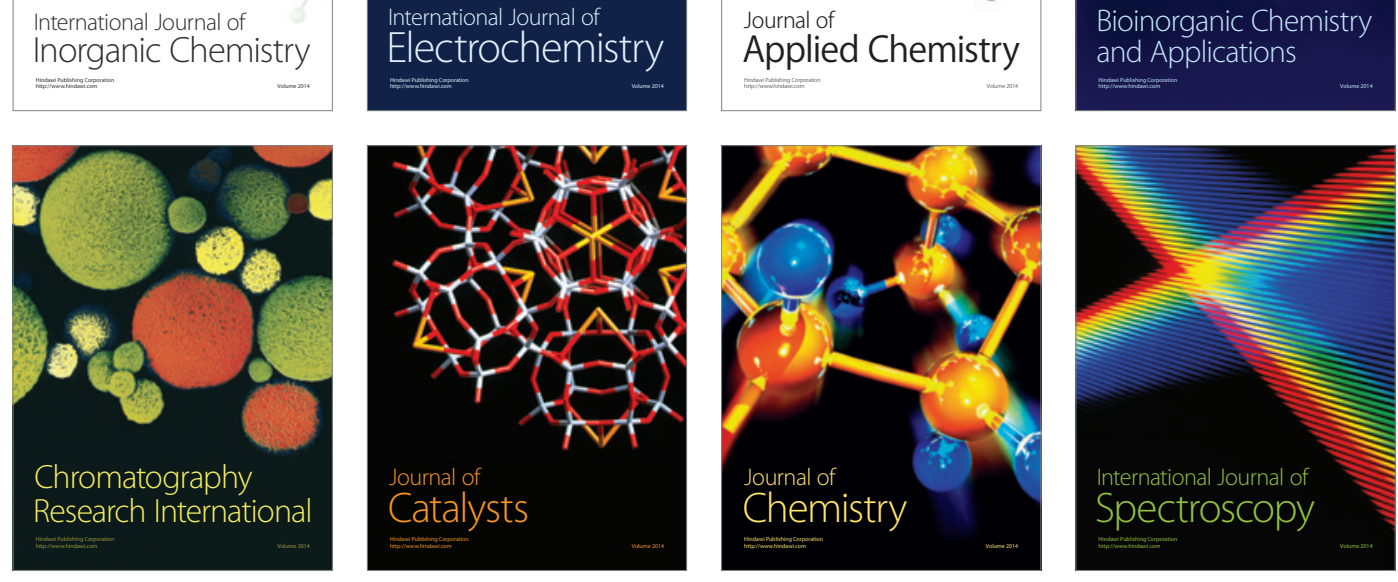